\title{
A közép- és kelet-európai országok vallásgyakorlatának regionális vonatkozásai
}

\author{
Regional aspects of religious activity in \\ Central and Eastern Europe
}

\author{
BALASSA BERNADETT
}

BALASSA Bernadett: doktorjelölt, egyetemi tanársegéd, Széchenyi István Egyetem, Regionális- és Gazdaságtudományi Doktori Iskola; 9026 Győr, Egyetem tér 1.; balassa.bernadett@sze.hu; https://orcid.org/0000-0002-6473-3591

KULCSSZAVAK: vallás; társadalmi tőke; regionális identitás; Közép- és Kelet-Európa

ABSZTRAKT: Szociológiai kutatások szerint a rendszerváltást követően nem mutatható ki a vallás visszaszorulása Közép- és Kelet-Európában. Néhol ugyan az individuális vallásgyakorlás jellemzővé vált, a vasfüggöny lebomlását követően fellendülő hitélet tapasztalható a régióban. A leírt tendencia irányítja a kutatók figyelmét a vallás mint identitásképző és kultúraalakító tényező felé. A tanulmány rámutat a régió Nyugat-Európától eltérő vallási sajátosságaira és az ahhoz illeszkedő vallásszociológiai elméletekre. A publikáció kiindulópontja egy egyéves kutatás, melyben Közép- és Kelet-Európa vallási és gazdasági összefüggéseit vizsgáltam. A kutatási projekt legfőbb eredményeinek bemutatása után a tanulmány a regionális vonatkozásokra koncentrál, így a térség tizenhárom országát - Albánia, Ausztria, Bulgária, Csehország, Észtország, Horvátország, Lengyelország, Lettország, Litvánia, Magyarország, Románia, Szlovákia és Szlovénia - vallási szempontból csoportosítja. A tanulmány konklúziója, hogy a vallás Közép- és Kelet-Európában a nemzeti és regionális identitás meghatározó aspektusa, aminek közvetlen gazdasági hatásai is kimutathatóak. Az egyes országok vallásgyakorlata a társadalmi és humán tőkébe való befektetésként válik a területi tőke meghatározó komponensévé.

Bernadett BALASSA: PhD candidate, assistant lecturer, Doctoral School of Regional Sciences and Business Administration, Széchenyi István University; Egyetem tér 1., H-9026 Győr, Hungary; balassa.bernadett@sze.hu; https://orcid.org/0000-0002-6473-3591

KEYWORDS: religion; social capital; regional identity; Central and Eastern Europe

ABSTRACT: Sociological studies suggest that there is no decline in Central and Eastern European religious activities after the collapse of the Soviet Union. It is true, that religion has individualised in some places in the region, but elsewhere there is an increase in traditional church attendance. These trends justify investigations of the effects of religion as a key factor in identity formation.

The study is based on a one-year research on the impact of religious activity on the economies of Central and Eastern Europe. The project contains two main statements about the

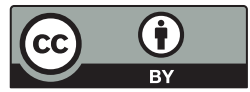


region: 1. There is a significant negative relationship between religious pluralism and church attendance; 2. Socio-economic indicators at macro level have significant correspondences with religious characteristics: there is an indirect linkage between religious belief and economic development in the region. This study focuses on the regional aspects of the research findings, in particular which forms of capital are accumulated by religious activities and organisations.

By reviewing the most current theories of social capital, the study categorises the ways religion affects the accumulation of territorial capital. It describes the religious characteristics of Central and Eastern Europe and classifies thirteen countries (Albania, Austria, Bulgaria, Croatia, Czechia, Estonia, Hungary, Latvia, Lithuania, Poland, Romania, Slovakia and Slovenia) according to religious indicators. The classification shows in which countries religious belief is strong as indicated by active church attendance, which in turn can be used for measuring social capital.

The results of the study strengthen those theories which interpret religious activity as an investment in human and social capital. According to the classification, in Poland and Romania religion could play a key role in the accumulation of social capital because of their strong religious belief and activity. Although further investigations are needed to highlight the direct linkage between the indicators of social capital and religion in the region, this study outlines the main theoretical correlations. Religion generates social capital by adding common norms for the communities, building trust, tolerance and solidarity. At the same time, religious organisations stimulate volunteering and open-handedness in solving social problems. In summary religion in Central and Eastern Europe is a key determinant of national and regional identity, as well as a source of capital accumulation which has a direct impact on the economy.

\section{Bevezetés}

A tanulmány célja egy egyéves kutatási projekt ${ }^{1}$ során megismert összefüggések regionális vonatkozásainak feltárása, egy lehetséges magyarázó modell megalkotása. A 2017/2018-as tanévben zajlott egyéni kutatás a közép- és kelet-európai makrorégióban láncszerü összefüggést tárt fel az országok vallási és társadalmi-gazdasági mutatói között. Jelen tanulmány a kapott eredményeket értelmezi két regionális gyűitőelmélet, a területi tőke és a társadalmi tőke elméleteinek fényében. A tanulmány első része röviden összegzi a kutatás legfőbb eredményeit, a vizsgálat főbb fogalmait és mérési eszközeit. Ezt követően az írás a területi tőke komponenseként a társadalmi tőke képződésének módjait szemlézi, melyben meghatározó szerep juthat a vallási közösségeknek. A tanulmány vége a közép- és kelet-európai térségben kapott eredményeket a téma kurrens szakirodalmával veti össze, valamint a régió országainak vallási szempontú csoportosítása révén a vallás tőkeképződéshez való hozzájárulását vizsgálja.

\section{Közép- és Kelet-Európa vallási-gazdasági összefüggései}

Az Új Nemzeti Kiválóság Program keretében tizenhárom közép- és kelet-európai ország vallási mutatóit és gazdasági indikátorait vizsgáltam (Balassa 2018a, 2018b), jelen írásban csak a tárgyhoz kapcsolódó legszükebb eredményeket 
mutatom be. A kutatás kimenete számos új kérdést vetett fel, melyekre a kutatás korábbi szakaszában nem találtam kielégítő magyarázatot. Jelen tanulmány a társadalmi tőke elméletével összevetve új megvilágításba helyezi a kapott eredményeket.

\section{A vizsgálat konceptuális alapjai}

Vallás alatt olyan meggyőződések, cselekedetek és intézmények megosztását értjük, melyek természetfeletti erők működésébe vetett hiten alapulnak (Iannaccone 1998). Ez a definíció Thomas Luckmann (1996) meghatározásával szinkronban nem csupán a szervezeti keretek között müködő, intézményi hitvallással megalapozott vallásosságot fedi, hanem a transzcendenciaélményt kereső spiritualitás egyéni megnyilvánulásait is. Az elmúlt évszázadban számos kutatás szerint gyengült a vallás társadalmi jelentősége (Bruce 2002; Norris, Inglehart 2004), ugyanakkor sokan cáfolják ezt a nézetet, köztük Luckmann is (1967). Iannaccone és Luckmann definícióját követve kutatásom sem korlátozta a vallásgyakorlást a tradicionális formákra, hanem az új típusú felekezetek, vallási irányzatok és a szertartáson kívüli egyéni hitgyakorlat is a vizsgálat tárgyát képezte. Egyes kutatók megállapítása szerint a modern korra a szekularizáció, mások szerint az individualizáció, valamint a racionális döntéshozatal, legújabban pedig a deszekularizáció jellemző.

A klasszikus liberalizmus fontos alapelve az egyház és az állam szétválasztása (Locke 1824). A modernitás kialakulásával egy időben Nyugat-Európában a vallás veszített intézményi és politikai súlyából és egyre inkább a magánélet berkei közé szorult. A jelenséget széles körűen ragadja meg a szekularizáció fogalma. Egyházjogi és filozófiai értelemben szekularizáción az egyházi tulajdon magán- vagy állami tulajdonba kerülését, az egyház befolyásának visszaszorítására irányuló állami törekvéseket értjük, ami lehetővé tette a világi (szekuláris) államok létrejöttét (Szőke 1999). A vallásszociológia klasszikusai, mint Émile Durkheim (2001) és Max Weber a társadalmi folyamatok leírásaként, szélesebb értelemben fogalmazták meg szekularizációs tézisüket. Eszerint a modern korral a vallás a társadalmi élet egyre kisebb szegletébe húzódott, a világ varázstalanná vált. Makroszinten a vallás így a társadalomszervezés számtalan alrendszere közül csupán egyet képvisel.

Számos kutató a szekularizáció mezoszintű megnyilvánulásaként értelmezi a tradicionális egyházak háttérbe szorulását, az újabb vallási szolgáltatók, felekezetek megjelenését. Ez a fajta vallási pluralizmus a német származású Berger (1969) szerint negatív kapcsolatban áll az egyházlátogatás gyakoriságával, ami a nyugat-európai államokra be is igazolódott (Pickel 2013). Az európai megfigyelésekkel egyidejüleg Észak-Amerikát és főként az Egyesült Államokat leíró vizsgálatok azonban cáfolják az összefüggést. Stark és Iannaccone (1994) racionális döntéselmélete a vallást is piacként értelmezi, amelyben a bővülő kínálat serken- 
tőleg hat a keresletre. Közvélemény-kutatási adatokra hivatkozva állítják, hogy a vallási diverzitás nemhogy csökkenti (szekularizációs hatás), hanem erősíti a transzcendenciába vetett hitet, az egyházlátogatást.

A szekularizáció mikroszintű megnyilvánulásának tekinthetjük a vallási individualizációt, az egyháztagok passzivitását és a gyakori felekezetváltást. Luckmann (1967) individualizációs tézise szerint az intézményesült keretek helyett felértékelődött a személyes hitgyakorlás, a vallás privatizációja. Az individuális hitgyakorlásban meghatározó a hívők egyéni preferenciája, esetenként több vallás tanításából „barkácsolják össze” saját hitüket. Az individualizációs tézis támogatói szerint a személyes hit mértéke antropológiailag meghatározott, viszonylag állandónak tekintheto", így alacsonyabb egyházlátogatási szokások mellett sem beszélhetünk a vallás jelentőségének csökkenéséről (Korpics, Wildmann 2010).

A fenti három elmélet (szekularizáció, individualizáció és racionális döntések) mindegyike a modernitás vallásra gyakorolt hatásával foglalkozik. A hatások sokszínűségéből ugyan látszik, hogy az intézményesült keretek között zajló vallásgyakorlás a világ egyes részein csökken, miközben Latin-Amerikában ezen a téren is fellendülés tapasztalható (Pew Research Center 2014a). A szociológiai szempontból, legszélesebb spektrumon (makro-, mezo- és mikroszint) értelmezett szekularizáció főként Nyugat-Európa sajátja (Pollack 2003), a közvéleménykutatási eredmények leginkább ebben a térségben igazolják a vallás háttérbe szorulását.

A gazdasági fejlődés és a vallásosság között a 19-20. században meghatározó szekularizációs elmélet alapján negatív kapcsolat áll fenn. Az egyéni anyagi biztonság és hitgyakorlás közötti kapcsolatot írja le Máté-Tóth András (2014, 58.): „az agrártársadalmaknak az ipari társadalmakba való átmenete révén a hétköznapi életrizikók csökkentek, megnövekedett a szociális biztonság, melyek a vallásra mint kontingenciakezelő instanciára vonatkozó igényt csökkentették". Az elmúlt évtizedekben a kutatók között növekvő érdeklődés tapasztalható a fordított relációt, tehát a vallás gazdaságra gyakorolt hatását illetően. A megnövekedett érdeklődés hátterében a vallás jelentőségének erősödése, a deszekularizáció (Berger 1999) következő jelenségei állnak.

- A nagy világvallások missziós tevékenysége az elmúlt évtizedekben megélénkült.

- A világvallások fundamentalista fókusza erősödik (Iannaccone 1998).

- A vallás geopolitikai jelentősége megnövekedett (Huntington 2015).

Az egyéves kutatási projekt során a fenti elméletek gyakorlati leképződését vizsgáltam Közép- és Kelet-Európában, valamint az aggregált vallási mutatók és a társadalmi-gazdasági indikátorok összefüggéseit elemeztem. 


\section{A kutatás módszereiról}

A kontinentális Európa országainak régiós besorolására számos földrajztudományi és történettudományi megoldás született (többek között Enyedi 1978; Niederhauser 2001; Szűcs 1983), kutatásomban az OECD (2000) definícióját használtam Közép- és Kelet-Európa meghatározására. Eszerint Albánia, Bulgária, Csehország, Észtország, Horvátország, Lengyelország, Lettország, Litvánia, Magyarország, Románia, Szlovákia és Szlovénia tartozik a térségbe. Az osztrákmagyar együttélés meghatározó időszakaira, valamint a közös vallási hagyományokra tekintettel Ausztria is bekerült a vizsgált országok közé.

A vallás gazdaságra gyakorolt hatását empirikus módszerekkel számos kutatás vizsgálta, saját elemzésem főként Barro és Mccleary (2003), Becker és Woessmann (2010), Forgács és Csillik (2017), Glahe és Vohries (1989), valamint Young (2009) módszerére, főbb megállapításaira támaszkodott. ${ }^{2}$ A közép- és kelet-európai térség vallási mutatóinak összehasonlítására több szociológiai tanulmány is született - többek között Harrach (2013), Máté-Tóth (2014); Pew Research Center (2017); Tomka (2011); Tomka, Zulehner (2008) -, ugyanakkor a vallási és gazdasági mutatók egymásra hatásával csak részlegesen foglalkoznak a kutatások. Két hipotézist fogalmaztam meg:

- Közép- és Kelet-Európában a vallási diverzitás szignifikáns pozitív kapcsolatban van az egyházlátogatás gyakoriságával.

- Közép- és Kelet-Európában a gazdasági fejlettségi mutatók statisztikailag szignifikáns összefüggést mutatnak a személyes vallási mutatókkal.

A kérdéseket korreláció- és regresszióelemzéssel vizsgáltam, SPSS program segítségével. A személyes vallási indikátorokat (endogén tényezők) a Pew Research Center kutatásai alapján három nagy egységre bontottam: 1. a meggyőződés foka (hit Istenben, mennyben és pokolban, a bűnök létezésében); 2 . az egyházlátogatás gyakorisága; 3. az egyéni hitgyakorlat (az imádkozás gyakorisága). A személyes jellemzőket a European Value Survey (EVS) 2008-as adatfelvételéből aggregáltam országos szintre. ${ }^{3} \mathrm{Az}$ aggregálást átlag szerint végeztem el, ${ }^{4}$ a keletkezett új mutatók skálaszintű változók.

Az aggregált vallási mutatókat Barro és McCleary (2003) alapján az államra vonatkozó vallási indikátorok mint exogén tényezők befolyásolják, így elsőként ezek személyes vallási tényezőkre gyakorolt hatását vizsgáltam. A mutatók és a hozzájuk tartozó adatforrások:

- Állami szabályozás, a vallásszabadság mértéke: GRI (Government Regulation of Religion Index), 2008 - ARDA-adatbázis (http://www.thearda.com/).

- Állami juttatások, támogatások rendszere: GFI (Government Favoritism of Religion Index), 2008 - ARDA-adatbázis.

- Nemzeti felekezeti megoszlás - cenzusadatok, a CIA World Factbook ${ }^{5}$ és az ARDA-adatbázis alapján.

- Vallási diverzitás (Religious Diversity Index, RDI) - a felekezeti megoszlás

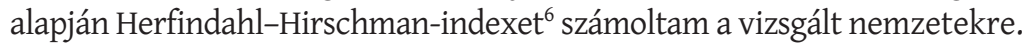


Az elemzési logika meghatározásakor korábbi nemzetközi kutatások eredményeit vettem figyelembe (Barro, McCleary 2003; Becker, Pfaff, Rubin 2016). Eszerint a fenti országos vallási mutatók csak a személyes vallásosság mutatóival (a hit mértéke, az egyházlátogatási gyakoriság, a szertartáson kívüli hitgyakorlás) állnak közvetlen kapcsolatban, míg a gazdasági fejlettségi mutatókkal nem. Az állami vallási mutatókat a kutatók többnyire köztes, instrumentális változóként kezelték a regressziós modellekben.

A személyes vallási mutatók hatását az egyes országok társadalmi-gazdasági indikátoraira vizsgáltam. Függő változóim a HDI (Human Development Index - emberi fejlettségi index) részmutatói voltak, így az egy före jutó vásárlóerő-paritáson mért GDP, az iskolázottság, valamint a születéskor várható élettartam (az adatok forrása: http://data.un.org/). A változókat a 2008-as évre gyűjtöttem ki, ez alól kivételek a 2010 körüli cenzusokból származó felekezeti megoszlások.

\section{A vizsgálat föbb eredményei}

Az első hipotézis tesztelésére regresszióelemzést végeztem. A vizsgált térségben statisztikailag szignifikáns, erős kapcsolat van a vallási diverzitás és az egyházlátogatás gyakorisága között, a Spearman-féle korreláció értéke -0,656. A lineáris regresszió alapján a vallási diverzitás 37,8\%-ban határozza meg az egyházlátogatás országos gyakoriságát; tehát minél plurálisabb a közép- és keleteurópai országok felekezeti megoszlása, annál ritkább az egyházlátogatás, Stark és Iannaccone (1994) elméletét cáfolva. A további állami vallási mutatók (GFI, GRI) nem mutattak szignifikáns összefüggést a hitbeli mutatók egyikével és a vallási diverzitással sem.

A személyes vallási mutatók között erőteljes kapcsolatot találtam. Az egyházlátogatás szignifikáns pozitív összefüggésben áll a különböző hitbeli meggyőződésekkel. Az Istenben való hit például erős szignifikáns kapcsolatban áll az egyházlátogatással (Pearson-féle korrelációs együttható: 0,765), a bűnök létezésében való hittel pedig még erőteljesebb az együttmozgás (Pearson-féle korrelációs együttható: 0,835 ).

Barro és McCleary (2003) tanulmányában a személyes vallási mutatók mindegyike szignifikáns összefüggésben áll a gazdasági fejlettség különböző mutatóival (az urbanizáció foka, a gazdasági teljesítmény stb.). Közép- és KeletEurópában a személyes vallásosság (hitbeli meggyőződések, egyházlátogatás és imádkozás) közül csupán két hitbeli meggyőződés áll szignifikáns kapcsolatban a társadalmi-gazdasági indikátorokkal, utóbbiak közül is csupán az iskolázottság szintjével. Az Istenbe vetett hit közepesen erős negatív (Pearson-féle korrelációs együttható: -0,532), míg a bünök létezésben való hit gyenge pozitív (Pearson-féle korrelációs együttható: 0,153) kapcsolatban áll az iskolázottság szintjével. A két mutatóval együttesen $57,4 \%$-os pontossággal becsülhetjük meg 
az iskolázottság szintjét. Természetesen a visszahatásról, a magasabb szintű iskolázottság istenhitet relativizáló, valamint az erkölcsösséget erősítő (a bűnök létezésébe vetett hit) hatásáról is beszélhetünk. A negatív összefüggéshez nagymértékben hozzájárult, hogy a leginkább szekuláris Csehország és Észtország a régió legmagasabb iskolázottsági értékeivel rendelkezik. Az iskolázottság és a személyes hit kapcsolatának vizsgálatát mindenképpen érdemes mikroszinten is elvégezni, egyéni adatok bevonásával.

Habár a további HDI-részmutatókkal nem állnak közvetlen kapcsolatban a személyes vallási mutatók, közvetett összefüggést sikerült kimutatni. Az oktatás színvonala közvetlen, közepesen erős szignifikáns kapcsolatot mutatott az egy före jutó GDP-vel (Pearson-féle korrelációs együttható: 0,552), míg a nemzeti jövedelem közvetlen hatással bír a várható élettartamra (Pearson-féle korrelációs együttható: 0,556). Ezáltal a vizsgált régióban igazoltnak látszik Becker és Woessmann (2010) elmélete, miszerint a vallásgyakorlás a humán tőkén keresztül befolyásolja a gazdasági fejlettséget, valahogy úgy, ahogy egykor a protestantizmus hozzájárult a kapitalizmus kialakulásához.

A világszerte végzett vallásszociológiai vizsgálatok eredményeihez képest Közép- és Kelet-Európa sok szempontból eltérő jellegzetességekkel bír. A korábbi tanulmányok kutatási módszertanát régiónkban alkalmazva csupán a vallási-gazdasági összefüggéseknek egy része igazolódott vissza. Ugyan nem látunk közvetlen kapcsolatot minden egyes spirituális és materiális indikátor között (1. ábra), a két szféra egymásra hatása igazoltnak látszik.

1. ábra: Vallási és gazdasági mutatók láncszerű kapcsolata Közép- és Kelet-Európában Chain-like relationship between religious and economic indicators in the region

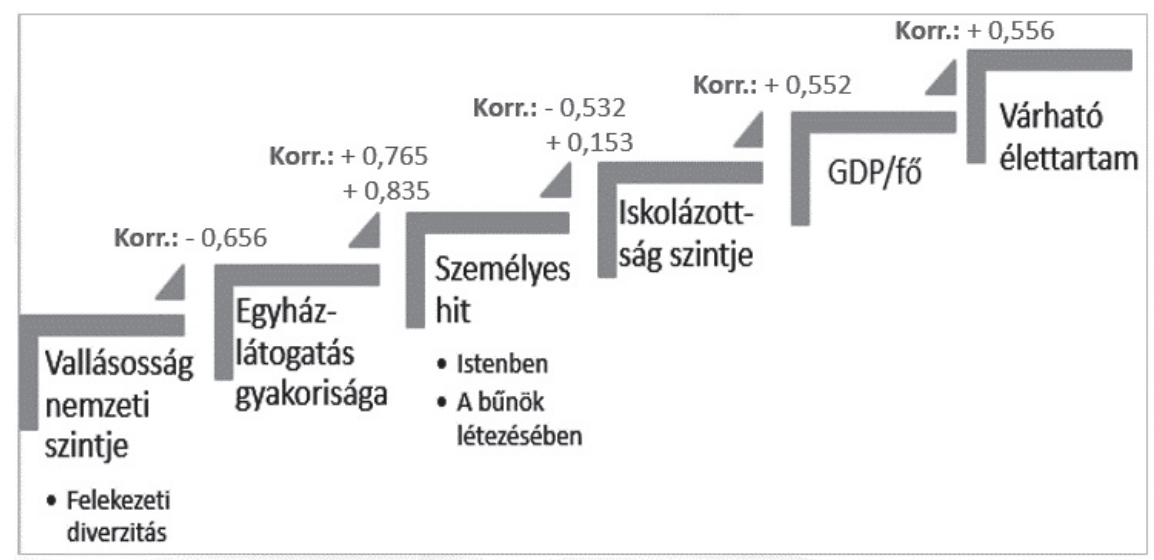

Forrás: Saját szerkesztés. 


\section{A kutatási eredmények regionális vonatkozásai}

A kutatás lebonyolítását követően az alábbi kérdések merültek fel:

- Vajon a vallási tényezők csak a humán tőkén keresztül gyakorolnak hatást a gazdaságra?

- Milyen szerepet játszik a társadalom vallásgyakorlata a gazdaság tőkeképzésében?

- Milyen jellegű tőke képződhet a vallásgyakorlás hatására?

- Mennyire különbözik egymástól az egyes országok vallási életének befolyása a társadalmi-gazdasági folyamatok alakulására?

Máté-Tóth András vallásszociológus arra hívja fel a figyelmet, hogy az egyes országok eltérő vallási mutatóinak hátterében „nem annyira a modernitás foka, hanem inkább az egyház, az állam, a nemzet és a civil társadalom viszonyrendszere a magas magyarázó erővel bíró faktor" (Máté-Tóth 2014, 56.). Nem elégséges tehát önmagában a modernitással vagy a gazdasági fejlettséggel összefüggésben vizsgálni egy térség vallási életének változásait, ehelyett a civil társadalom erőssége, a domináns vallás és a regionális identitás kapcsolata, a vallási felekezetek sokszínűsége erős befolyással bír az egyének hitgyakorlatára, és fordítva. A felsorolt kérdések és a vallásszociológus ajánlásai mentén a fenti kutatás eredményeit a regionális identitás és a társadalmi tőke elméleteinek főbb megállapításaival vetem össze.

\section{A területi tőke mint a regionális fejlödés endogén forrása}

Marx várakozása szerint az anyagi tőke felhalmozódása maga után vonja a monoteista hit „ködszüleményeinek” eloszlását, a modernitással egyidejüleg a vallásgyakorlás visszaszorulását (Lenin 1971, 48-50.). Azóta számos közgazdász egészítette ki tőkeelméletét olyan megfogható és kevésbé tárgyiasult, korlátozottan és szinte korlátlanul rendelkezésre álló erőforrásokkal, melyek szintúgy szerepet játszanak a versenyképesség és termelékenység fokozásában. Az elmúlt évtizedek szociológiai kutatásai alapján egyre inkább elképzelhetőnek látszik, hogy egy térség meghatározó hitgyakorlata is képes hozzájárulni annak gazdasági fejlődéséhez, így felértékelődik a tőkeképződés vallási dimenziója.

Nan Lin $(2001,4$.) szerint a tőke olyan befektetett erőforrások halmaza, melyekért további erőforrásokhoz juthatunk a piacon, értéktöbbletet generálva. Egy régió endogén fejlődésében nem csupán a tárgyiasult gazdasági tőke játszik meghatározó szerepet, hanem egy sor kevésbé tárgyiasult tőketényező is (Lengyel 2012). Habár a közgazdasági szakirodalomban pontosabb konceptualizáció vár még a területi tőke fogalmára, a Camagni-féle elmélet megalapozottnak látszik, számos regionalista az ő modellére támaszkodik (Rechnitzer, Smahó 2011). Camagni (2008) cikkében a területi tőkét kilenc komponensre osztja, a rivalizálás mértéke (alacsony, közepes, magas) és a tárgyiasultság foka szerint. 
Elmélete alapján a területi tőke összetevőjeként a 2. ábrán felsorolt tőketípusokat érdemes figyelembe venni a helyi sajátosságokon alapuló versenyképesség elemzésekor. A területi tőke egy adott területen elérhető inputok összessége, melyek további javak képződéséhez járulnak hozzá. A háromszor hármas mátrix csúcsaiban helyet foglalnak a marxi értelemben vett klasszikus magánjavak, a szakmai képességeket és készségeket tömörítő emberi tőke, a szociológiai irodalomban mérvadóvá vált társadalmi tőke, valamint a természeti és épített erőforrásokat összesítő közjavak. A további öt tőketényező főként vegyes javakat és mezoszintű erőforrásokat jelenít meg. Míg az első oszlopban található tárgyi javak viszonylag jól számszerűsíthetők, az utolsó oszlopban felsorolt humán tőke, kapcsolati tőke és társadalmi tőke azok szoft jellegéből fakadóan egzaktan kevésbé mérhető.

2. ábra: A területi tőke komponensei

Components of territorial capital

\begin{tabular}{|c|c|c|c|}
\hline $\begin{array}{r}\text { Magas rivalizálás } \\
\text { (magán } \\
\text { javak) }\end{array}$ & $\begin{array}{l}\text { Pénzben kifejeződő } \\
\text { externáliák (hard) }\end{array}$ & $\begin{array}{l}\text { Kapcsolati magán } \\
\text { szolgáltatások: } \\
\text { - a cégek külsö } \\
\text { kapcsolatai } \\
\text { - K+F eredmények } \\
\text { transzfere } \\
\text { Egyetemi spin-offok }\end{array}$ & $\begin{array}{l}\text { Humán tőke: } \\
\text { - vállalkozókészség } \\
\text { - kreativitás } \\
\text { - magán know-how } \\
\text { Pénzben kifejeződő } \\
\text { externáliák (soft) }\end{array}$ \\
\hline $\begin{array}{lr}\mathbf{R} & \\
\mathbf{i} & \text { (klub } \\
\mathbf{v} & \text { javak) } \\
\mathbf{a} & \\
\mathbf{l} & \\
\mathbf{i} & \\
\mathbf{z} & \\
\mathbf{a} & \text { (kevert } \\
\mathbf{l} & \text { közjavak) }\end{array}$ & $\begin{array}{l}\text { Tulajdonosi (saját) } \\
\text { hálózatok } \\
\text { Kollektív javak: } \\
\text { - tájkép } \\
\text { - kulturális örökség } \\
\text { (magán 'együttesek') }\end{array}$ & $\begin{array}{l}\text { Kooperációs hálózatok: } \\
\text { - stratégiai szövetség } \\
\text { K+F-ben és tudásban } \\
\text { - PPP a szolgáltatásokban } \\
\text { és tervezésben } \\
\text { Természeti és kulturális } \\
\text { eröforrásokkormányzása }\end{array}$ & $\begin{array}{l}\text { Kapcsolati tőke: } \\
\text { - együttmüködési } \\
\text { képesség és kollektív } \\
\text { tevékenység } \\
\text { - kollektív kompetenciák }\end{array}$ \\
\hline (közjavak) & $\begin{array}{l}\text { Erőforrások: } \\
\text { - természeti } \\
\text { - kulturális } \\
\text { Társadalmi állótőke: } \\
\text { - infrastruktúra }\end{array}$ & $\begin{array}{l}\text { Ügynökségek a K+F } \\
\text { transzferére } \\
\text { Befogadóképesség az új } \\
\text { eszközök iránt } \\
\text { Agglomerációs és } \\
\text { körzeti elönyök }\end{array}$ & $\begin{array}{l}\text { Társadalmi töke: } \\
\text { (önkéntes részvétel) } \\
\text { - intézmények } \\
\text { - magatartásminták, értékek } \\
\text { - bizalom, reputáció }\end{array}$ \\
\hline acsony rivanzalas & $\begin{array}{c}\text { Tárgyi javak } \\
\text { (hard) }\end{array}$ & $\begin{array}{l}\text { Vegyes javak } \\
\text { (hard + soft) }\end{array}$ & $\begin{array}{l}\text { Nem tárgyi javak } \\
\text { (soft) }\end{array}$ \\
\hline
\end{tabular}

Tárgyiasultság

Forrás: Camagni $(2008,38$.$) alapján Lengyel (2012,162$.$) .$ 


\section{A társadalmi tóke szerepe a gazdaságban}

A területi tőke elemei közül jelen tanulmány szempontjából kiemelkedik a normákat, bizalmat és társas hálózatokat tömörítő társadalmi tőke. A fogalom megalapozásában kiemelkedő tevékenységet végzett három szociológus, Pierre Bourdieu, James S. Coleman és Robert D. Putnam, az irodalmat magyar nyelven Nagy Gábor Dániel $(2016)$ tekinti át. Bourdieu $(1979,133$.$) megfogalmazásában a$ társadalmi tőke a tiszteletre méltóság tőkéje, amely szükséges a társadalomban való létezéshez, a bizalom megszerzéséhez, konkrét gazdasági és politikai hasznokat indukál. Definíciója ráirányítja figyelmünket a társadalmi tőke egyik fó komponensére, a bizalomra, amely a tranzakciós költségek csökkentése révén közgazdasági számítások alapján (Coase 1960) is gazdasági értéktöbblethez vezet. Coleman (1988) a közös normák és értékek létrehozásának, fenntartásának szükségességét hangsúlyozza, melyek alapul szolgálnak a jól működő, egészséges társadalmi együttéléshez. Putnam, Leonardi, Nonetti (1993) a közös munkavégzésre való hajlandóságban, a kölcsönös haszonszerzésen alapuló reciprocitásban ragadják meg a társadalmi tőke lényegét. A szolidaritás, azaz a hajlandóság az azonnali viszonzás nélküli adásra szerinte a közjó megteremtésének kulcsa, ebben nélkülözhetetlen szerep jut a polgári erények meglétének (Putnam 2000). A társadalmi tőke keletkezésében Eva Cox (1995) az előzőek mellett a különbségek tolerálását, a közösségekhez való tartozást, az aktív részvételt és együttmüködést, a szociális szükségletek felismerését és kezelését emeli ki.

Onyx és Bullen $(2000,25$.$) megfogalmazásában a társadalmi tőke fenti ele-$ meinek (bizalom, reciprocitás és közös normák, hálózatok) együttes hatása következtében erős közösségek jönnek létre, amelyek által közösen birtokolt vagyont (társadalmi tőke) mindenki használja, de senki sem bitorolja. Ez egybecseng Camagni (2008) csoportosítával, ahol a társadalmi tőke sajátos jellegzetessége az alacsony fokú rivalizálás, hiszen a tőkeelem birtoklása közös, senki sem zárható ki belőle, és a közös használat révén elvileg korlátlan mértékben növekszik az erőforrás mennyisége. A társadalmi tőke tehát olyan tőketényező, amelyet minél inkább használunk, annál több lesz belőle: a bizalom bizalmat szül, a segítő szándékot viszonozzák.

Putnam, Leonardi, Nonetti (1993) az olasz tartományok eltérő versenyképességének hátterében a társadalmi tőke különböző minőségét jelölték meg. Esettanulmányaik alapján az északi területek sikerét magasabb mértékủ társadalmi tőkéjük - bizalmuk, szolidaritásuk és toleranciájuk - alapozta meg, míg az elmaradottabb déli térségek a bizalom hiánya, a kooperáció megvalósíthatatlansága miatt szenvedtek hátrányt. Előbbiek esetében erőteljesebb területi kötődés, identitás volt kimutatható, mint a déli tartományokban, így a szerzők a területi identitás és a társadalmi tőke kölcsönhatására is felhívják a figyelmet. Nagy Gábor Dániel szintén rámutat a területi kötődés és a társadalmi tőke összekapcsoltságára. A két fogalom meghatározása a szerző szerint jelentős átfedéseket mutat, „a területi identitás, illetve mérésre operacionalizálható része, 
a területi kötődés, a társadalmi tőke elmélet egy dimenziójaként funkcionál a területi egységek helyi társadalmainak esetében" (Nagy 2016, 80.). Az adott földrajzi térben koncentrálódó bizalom és reciprocitás, a társadalmi hálózatok száma és minősége, a civil aktivitás, a társadalmi integráció mértéke a területi kötődés indikátoraként jelennek meg, az adott térség társadalmi tőkéjét számszerüsítik.

\section{A vallásgyakorlás hatása a tôkeképződésre}

A társadalmi tőkeképződés meghatározó színterei az önkéntes társulások, melyek tagjai szabad belátásból csatlakoznak a szervezethez, felépítésük és irányításuk racionális, céljuk a kollektív cselekvés elősegítése (Weber 1987). Ezeknek a szervezeteknek a létrejöttében erőteljes befolyással bír a szocializáció és a vallási háttér. A társadalmi tőke keletkezésében kiemelt szerepet játszhat a vallás, amint ezt az elmélet alátámasztja (Putnam 2000). Elsőként a vallás társadalmi tőkeképzésre gyakorolt hatását, majd annak korlátait mutatom be.

1. A vallási közösségek sok esetben maguk is önkéntes társulások, melyek erősítik a társadalmon belüli hálózatosodást.

2. A vallási közösségek terjesztik az önkéntességet és az adományozást, ráirányítják a figyelmet a társadalmi szükségletekre, lehetőséget biztosítanak tagjaiknak a vallási szervezeten belüli és kívüli szolgálatra (Greeley 1997).

3. A közösségek szocializációs funkciót töltenek be, tudást és képességet biztosítva tagjaiknak a közösségi együttéléshez, ami a hívek társadalmi integrációját is erősítheti.

4. Állami és önkormányzati feladatok átvállalásával a vallási közösségek csökkentik a kiadásokat, oktatási és szociális intézményeket tartanak fenn, nem csak tagjaik számára.

5. Sok esetben közéleti szerepvállalásra, politikai részvételre buzdítanak (Wuthnow 1999).

6. A rendszeres egyházlátogatás védőhálót biztosít a társadalmi életben való érvényesüléshez (pl. Coleman 1988 eredményei alapján csökkenti az iskolai lemorzsolódást).

7. A vallási közösségek tagjai általában a társadalom legkülönbözőbb osztályaiból érkeznek, az egymás melletti hitgyakorlás erősíti a toleranciát, esélyegyenlőséget biztosít a hátrányos helyzetű tagok számára is.

8. Közös normák, értékek terjesztésével nem csupán a közösségen belül, hanem azon kívül is hatást gyakorolnak a társadalomra (Schmidt 2017).

9. Tanításaikban többnyire az embertársak tiszteletére és szeretetére ösztönöznek, ami erősíti a polgári erényeket.

A fenti felsorolás korlátja, hogy zömében az Egyesült Államok domináns vallási közösségeire fogalmazták meg őket, így elsősorban keresztény felekezetekről szólnak azok. Másrészt nem minden vallási közösség járul hozzá egyfor- 
mán a társadalmi tőke megteremtéséhez, befolyásuk eltérő típusú és volumenű lehet. Bizonyos esetekben akár a társadalmi integráció hátráltatója is lehet egyegy deviáns közösség. Utóbbiak közé sorolhatók a vallási közösségek klasszikus csoportosítása szerint azok a szekták, melyek negatív viszonyban állnak a társadalommal, a csoport tagjai a társadalmi normákkal szembemenő üzeneteket és magatartást, elkülönülést tanúsítanak (McGuire 2001). A vallás társadalmi hatásait vizsgálva így érdemes szemügyre venni a vizsgált országok domináns felekezeteit, a hívők egyházlátogatási gyakoriságát, ugyanis többnyire az intézményesült vallásgyakorlattal kapcsolatban állapítják meg a kutatók a tőkeképző hatásokat. Magyarországról például Nagy Gábor Dániel (2016, 157.) esettanulmánya azt a következtetést vonja le egyházlátogatási statisztikák alapján, hogy jelen pillanatban nem indokolt a vallást jelentős társadalmitőke-dimenzióként értelmezni az országban. Visszakapcsolódva az elmúlt évben végzett közép- és kelet-európai vizsgálat (Balassa 2018a) eredményeihez, érdemesnek tartom mélyebben áttekinteni a térség országainak vallásgyakorlatát, megvizsgálva, hogy jelenleg mely országokban kaphat jelentős szerepet a vallási dimenzió a társadalmi tőke felhalmozásában.

Az áttekintett irodalom főbb eredményei alapján a társadalommal pozitív viszonyt ápoló vallási közösségek képesek a társadalmi tőkéhez való hozzájárulásuk alapján az adott régió gazdasági versenyképességét is fokozni. Putnam (2000) tanulmányában további szoros, pozitív összefüggést találhatunk a képzettségi szint (humán tőke) és a társadalmi tőke között: általánosságban a magasabb fokú iskolázottság nagyobb interperszonális bizalmat, toleranciát és önkéntességre való hajlandóságot teremt. A társadalmi tőke és az emberi tőke fejlődésének összekapcsoltságáról ír Weiss (1996) is, elmélete a területi tőke két elemének szimultán gyarapodását támasztja alá. A területi tőke és identitás, a társadalmi tőke és a vallásgyakorlás elméleti összefüggéseit tartalmazza a 3. ábra. A tőkeelemek kapcsolódása segít értelmezni a vallás eddig megismert gazdasági hatásait, valamint új kutatási irányokat jelöl ki.

A hitgyakorlás regionális identitást befolyásoló szerepét támasztja alá Butlin (1990) és Somlyódyné Pfeil (2007) tanulmánya is. Előfordulhat azonban, hogy a vallás olyan módon játszik jelentős szerepet az adott társadalom összetartásában, hogy közben hagyományos vallási tartalma közömbös. Az Amerikai Egyesült Államok elnöki beiktató beszédeit elemezve Robert N. Bellah (1967) például arra a következtetésre jutott, hogy egy sajátos „civil vallás” jellemzi az országot. Ez a felekezetsemleges vallási orientáció, mellyel az amerikaiak többsége egyetért, nagyban hozzájárult az intézmények létrejöttéhez és jól körülhatárolható szimbólumrendszerben nyilvánul meg. A civil vallás „a közösség, a közéleti erkölcs, az állampolgári kötelesség és a társadalmi elkötelezettség értékeit hangsúlyozza, miközben kevéssé foglalkozik az egyéni hit, a lelki élet, a testvéri szeretet és az isteni megváltás hagyományos keresztény kérdéseivel" (Pintér 2014, 7.). Habár sokan bírálták Bellah elméletét, az a szekularizált vallásosság integráló, identitást fenntartó szerepére mutat rá. A szakirodalom azon- 
3. ábra: A területi tőke, társadalmi tőke és a vallásgyakorlat fóbb elméleti összefüggései Theoretical relations between territorial capital, social capital and religious activity

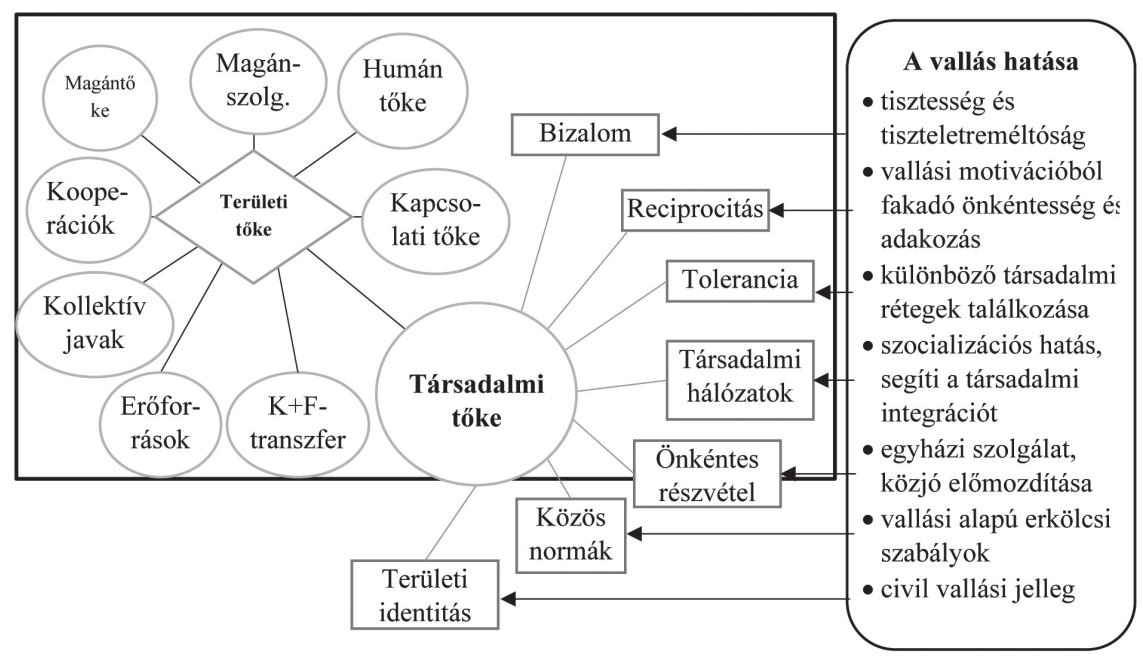

Forrás: Camagni $(2008,38$.) és Nagy $(2016,81 ., 176$.$) alapján saját szerkesztés.$

ban felhívja a figyelmet arra, hogy hosszú távú, stabil identitás abban az esetben várható, ha a hitgyakorlat és a vallás területi hovatartozást erősítő jellege összhangban áll egymással (Máté-Tóth 2014).

\section{Közép- és Kelet-Európa vallási dimenziója}

Az előbbiekben ismertetett elméletek és összefüggések fényében fordulok Közép- és Kelet-Európa vallási dimenziójának elemzéséhez, mely a hitgyakorlat térségbeli szerepére irányítja figyelmünket. A vizsgálatokat továbbra is másodelemzésként, az EVS, a CIA World Factbook és az ARDA korábban ismertetett adatbázisain végeztem.

\section{A térség vallási sajátosságai}

A vizsgált terület közel sem egységes, sem földrajzi, sem történeti, sem vallási szempontból. Máté-Tóth (2014) megközelítésében három közös jellemvonása mégis van a térségnek. Egyrészt az 1990-es fordulatot követően az országok politikai, gazdasági és társadalmi berendezkedése jelentős változásokat követelt, az egypártrendszerről a többpártrendszerre, a tervgazdálkodásról a piacgazdaságra való váltás a régió legfóbb jellemvonásának az átmenetiséget adta. Más- 
részt, pontosan a rendszerváltást követő átmenetiségből fakadóan az elmúlt évtizedekben társadalmi vákuum jött létre, hiszen megváltozott az érvényesülés módja, a társadalomszervezés korábban megszokott struktúrája. Harmadrészt bár jelentősen eltér az országok nemzetállami múltja, az állami szuverenitás iránti igény a régió közös sajátossága. A térség további megkülönböztető jegyei között említhetjük az atomizált társadalmat, a civil társadalom gyenge jelenlétét és a kommunista mentalitás tovább élését (Máté-Tóth 2014). Ausztria némiképp kilóg a sorból, hiszen a vasfüggöny nyugati oldalán helyezkedett el. Szerepe vallási viszonylatban is jelentős, hiszen II. József felvilágosult abszolutizmusa indította el a közép-európai országok vallási modernizációját, az állam egyházzal való viszonyának újragondolását (Fazekas 2008). Később az 1848-49-es forradalom és szabadságharc leverését követően I. Ferenc József az egyházi kiváltságjogok és hatalom megerősítését választotta, megújítva a térségben a katolikus egyház dominanciáját.

Vallási szempontból ugyan eltérő az egyes országok felekezeti diverzitása, vallásgyakorlásának intenzitása, mégis Nyugat-Európától különböző jellegzetességeket fedezhetünk fel benne (1. táblázat). A térség jeles vallásszociológusa, Tomka Miklós (2011) értékkutatások adatbázisaira támaszkodva azt állítja, hogy a rendszerváltást követően megnövekedett a vallás iránti kereslet a közép- és kelet-európai országokban, hiszen felszabadultak a vallásgyakorlás állami korlátozása alól. ${ }^{7}$ Megállapításait a Pew Research Center (2017) legfrissebb kutatása is alátámasztja. A délkelet- és kelet-európai országokat is magába foglaló vizsgálat szerint a rendszerváltás óta a vallási és nemzeti identitás egyszerre erősödik a szélesebb értelemben vett régióban. Felekezeti hovatartozás tekintetében főként az ortodox vallású országok egyházi tagsága növekedett, míg a katolikus dominanciájú államokban csökkenés tapasztalható.

1. táblázat: Közép- és Kelet-Európa vallási sajátosságai Religious characteristics of Central and Eastern Europe

\begin{tabular}{lll}
\hline \multicolumn{1}{c}{ Jellemvonás } & \multicolumn{1}{c}{ Nyugat-Európa } & \multicolumn{1}{c}{ Közép-és Kelet-Európa } \\
\hline A vallásosság megnyilvánulása & Egyházi hovatartozás nélküli hit $\begin{array}{c}\text { Hit és felekezethez tartozás, } \\
\text { aktív vallásgyakorlás nélkül }\end{array}$ \\
\hline $\begin{array}{l}\text { Az egyházak közéleti } \\
\text { tevékenységének támogatása }\end{array}$ & Alacsonyabb szintű & Magasabb szintű \\
\hline $\begin{array}{l}\text { A vallás konfliktusforrásként } \\
\text { (intolerancia) való értelmezése }\end{array}$ & Inkább jellemző & Kevésbé jellemző \\
\hline $\begin{array}{l}\text { A vallási intézményekkel } \\
\text { szembeni bizalom }\end{array}$ & Alacsonyabb szintű & Magasabb szintü \\
\hline $\begin{array}{l}\text { A szekularizációs tézis } \\
\text { beigazolódása }\end{array}$ & Inkább jellemző & Inkább nem jellemző \\
\hline
\end{tabular}

Forrás: Pew Research Center (2017, 7.) és Tomka (2011, 32., 50.).

Habár a civil társadalom ereje Közép- és Kelet-Európában általánosságban gyenge, az egyházak közéleti aktivitása, az ezzel kapcsolatos elvárás magasabb a 
nyugat-európainál. Ennek ténye a vallás társadalmi tőkeképződéshez való hozzájárulását sejteti, a közéleti részvétel terjesztésén keresztül. Régiónkban szintén tőkeképző hatása lehet a vallási közösségeknek a tolerancia, illetve az (egyházi) intézményi bizalom erősítése révén.

\section{A civil vallás identitásképző szerepe a régióban}

A Pew Research Center (2017) kutatási eredményei alapján a régió keleti részén sem a szekularizáció, sem az individualizáció nem érezteti hatását, míg Közép-Európa országaiban erőteljesebb az individuális (felekezet nélküli) hitgyakorlás. „A kelet-közép-európai kulturális régió minden országára inkább többé, mint kevésbé jellemző az etnikumok és nyelvek pluralitása, a történelmi folytonosságba való éles bevágások sűrűsége, a (nemzet)államiság megteremtésének vagy helyreállításának a kényszere. A régió politikai, gazdasági és kulturális turbulenciái civil vallással fémjelezhető folyamatokat igényelnek és erősítenek" - írja Máté-Tóth (2014, 225.). Hankiss Elemér (1991) nemzetvallásnak nevezi azt a közéleti szinten megnyilvánuló vallásosságot, amely a közép- és kelet-európai, volt szocialista, szuverenitásukhoz ragaszkodó országok sajátja. A Pew Research Center (2017) kutatása szintén a vallás és a nemzeti identitás összekapcsoltságát igazolta a régióban.

Az alapvetően észak-amerikai vallási folyamatokat leíró „civil vallás” elmélete Közép- és Kelet-Európa országaira az alábbiakban alkalmazható:

- az országok államalapítása szoros összefüggésben áll a kereszténység felvételével (pl. Szent István, 1000);

- történelemértelmezésük fontos dimenziója a keresztény kultúrkörhöz való tartozás (pl. 1795-1918 között a hiányzó nemzeti önállóság idején az egyház tartotta össze a lengyelséget);

- a vallás társadalmi funkciója az alapértékek hangsúlyozása, a közös nemzeti identitás megerősítése;

- célkitűzéssé vált az ún. keresztény Európa megvédése a nem keresztény (fóként muzulmán) hatásoktól (V4-törekvések);

- hangsúlyos módon jelennek meg egyházi szimbólumok a nemzeti zászlón és címeren, jogi szövegekben.

Fentiek mentén belátható, hogy a vallás társadalmi funkciója jelentős a térségben, a nemzeti identitás fenntartásának, az új társadalmi rendszerek legitimálásának hangsúlyos eszköze (ennek példája a katolikus egyház szerepvállalása az 1989-es lengyel rendszerváltásban). Amennyiben a regionális identitásra hatással van a vallás (Butlin 1990; Somlyódyné Pfeil 2007), úgy a civil vallási jelleg a térségbe tartozó országok fontos sajátossága, összekapcsoló eleme lehet.

Az erőteljes szimbolikus hatás ellenére a térségben a nemzeti politikákra mégsincs mindenhol közvetlen befolyással a hitgyakorlás. Máté-Tóth (2014, 
118.) csoportosításában a régió zöme a „szekuláris állam, szekuláris politika” elvet képviseli, míg a nemzetek kisebb csoportja alkalmaz vallásos politikát a szekuláris államban. ${ }^{8}$ A régió egészére vonatkozó megállapításokat követően érdemes országonként is megvizsgálnunk a térség vallási sajátosságait.

\section{Vallási klaszterek Közép- és Kelet-Európában}

A vizsgált sokaság országos vallási mutatóit közli a 2. táblázat. Közép- és KeletEurópában viszonylag magas a vallásosak aránya, ez alól kivételt Csehország és Észtország jelent. A régióban öt felekezet jelenléte volt statisztikailag kimutatható és összehasonlítható, így a katolikus, protestáns, ortodox, muszlim és zsidó vallásúak megoszlását elemeztem az egyes társadalmakban. A „nem meghatározott" kategóriába azok tartoznak, akik a népszámlálások során nem jelöltek meg konkrét felekezetet (felekezet nélküliek) vagy egyéb, relatíve kis létszámú felekezethez tartoznak. A régió domináns felekezetei a római katolikus valamint a nemzeti ortodox egyházak, Albániával pedig egy muszlim többségü lakosság is bekerült a vizsgálatba.

A 0-10 skálán mért vallási pluralizmus mutatói alapján a régió magas vagy nagyon magas diverzitású országa Lettország és Észtország, Albánia és Magyarország. Ezekben az államokban nemcsak a felekezetek száma magas, hanem azok aránya is viszonylag kiegyenlített. Kifejezetten alacsony vallási pluralizmus jellemzi a katolikus többségü Lengyelországot, Litvániát, Horvátországot, Szlovéniát és az ortodox Romániát.

2. táblázat: A vizsgált országok állami szintű vallási mutatói (2008) National religious indicators of the examined region (2008)

\begin{tabular}{llcccc}
\hline \multicolumn{1}{c}{ Ország } & $\begin{array}{c}\text { A legnagyobb arányú felekezet } \\
\text { a társadalomban (\%) }\end{array}$ & $\begin{array}{c}\text { A nem vallásosak } \\
\text { aránya a } \\
\text { társadalomban }\end{array}$ & $\begin{array}{c}\text { Vallási } \\
\text { diverzitás } \\
(\text { RDI })\end{array}$ & $\begin{array}{c}\text { Állami } \\
\text { szabályozás } \\
(\text { GRI) }\end{array}$ & $\begin{array}{c}\text { Állami } \\
\text { kedvezés } \\
(\text { GFI })\end{array}$ \\
\hline Albánia & Muszlim (56,7\%) & $2,5 \%$ & 6,43 & 0 & 0,67 \\
Ausztria & Katolikus (73,8\%) & $12,0 \%$ & 3,09 & 1,39 & 5,60 \\
Bulgária & Ortodox (59,4\%) & $9,3 \%$ & 3,24 & 5,28 & 7,03 \\
Horvátország & Katolikus (86,3\%) & $3,8 \%$ & 1,99 & 0 & 7,93 \\
Csehország & Nem meghatározott (47,7\%) & $40,0 \%$ & 3,65 & 0 & 4,70 \\
Észtország & Nem meghatározott (16,7\%) & $54,1 \%$ & 7,62 & 0 & 2,00 \\
Magyarország & Katolikus (37,2\%) & $16,7 \%$ & 6,10 & 0 & 2,83 \\
Lettország & Nem meghatározott (29,3\%) & $5,4 \%$ & 8,60 & 1,67 & 6,20 \\
Litvánia & Katolikus (77,2\%) & $10,3 \%$ & 1,83 & 0 & 7,93 \\
Lengyelország & Katolikus (87,2\%) & $4,3 \%$ & 0,60 & 0 & 2,83 \\
Románia & Ortodox (81,9\%) & $0,2 \%$ & 2,84 & 5,28 & 8,27 \\
Szlovákia & Katolikus (62,0\%) & $13,4 \%$ & 3,80 & 0,56 & 8,27 \\
Szlovénia & Katolikus (57,8\%) & $10,1 \%$ & 2,00 & 0 & 2,00 \\
\hline
\end{tabular}

Forrás: CIA World Factbook és ARDA-adatbzásisok alapján saját szerkesztés. 
3. táblázat: Vallási klaszterek Közép- és Kelet-Európában (klaszterátlagok, 2008) Religious clusters in Central and Eastern Europe (means, 2008)

\begin{tabular}{|c|c|c|c|c|}
\hline Ismérv & $\begin{array}{l}\text { Individuális } \\
\text { hitgyakorló }\end{array}$ & Bizonytalan hívo" & Szekuláris & Mélyen vallásos \\
\hline $\begin{array}{l}\text { Isten fontossága } \\
(1-10) \\
\end{array}$ & Fontos $(7,06)$ & $\begin{array}{l}\text { Fontos is, meg } \\
\text { nem is }(5,70)\end{array}$ & $\begin{array}{l}\text { Inkább nem fontos } \\
(4,20)\end{array}$ & $\begin{array}{l}\text { Nagyon fontos } \\
(8,32)\end{array}$ \\
\hline $\begin{array}{l}\text { Hit a pokol } \\
\text { létezésében (0-1) }\end{array}$ & Közepes $(0,40)$ & Gyenge $(0,32)$ & Gyenge $(0,19)$ & Erős $(0,76)$ \\
\hline $\begin{array}{l}\text { Hit a menny } \\
\text { létezésében (0-1) }\end{array}$ & Közepes $(0,51)$ & Közepes $(0,40)$ & Gyenge $(0,25)$ & Erős $(0,82)$ \\
\hline $\begin{array}{l}\text { Az egyházlátogatás } \\
\text { gyakorisága (1-7) }\end{array}$ & Ritka $(2,70)$ & Ritka $(2,20)$ & $\begin{array}{l}\text { Alkalmanként } \\
\text { vagy soha }(1,35)\end{array}$ & Rendszeres $(3,83)$ \\
\hline $\begin{array}{l}\text { Az imádkozás } \\
\text { gyakorisága (1-7) }\end{array}$ & Rendszeres $(3,63)$ & Ritka $(2,30)$ & $\begin{array}{l}\text { Alkalmanként } \\
\text { vagy soha }(1,49)\end{array}$ & Gyakori $(4,56)$ \\
\hline Klasztertagok & $\begin{array}{l}\text { Albánia } \\
\text { Horvátország } \\
\text { Szlovákia }\end{array}$ & $\begin{array}{l}\text { Ausztria } \\
\text { Bulgária } \\
\text { Lettország } \\
\text { Litvánia } \\
\text { Magyarország } \\
\text { Szlovénia }\end{array}$ & $\begin{array}{l}\text { Csehország } \\
\text { Észtország }\end{array}$ & $\begin{array}{l}\text { Lengyelország } \\
\text { Románia }\end{array}$ \\
\hline
\end{tabular}

Forrás: EVS-adatbázis alapján saját szerkesztés.

Az egyes országok vallásossága és hitgyakorlatának aktivitása alapján négy klaszterbe sorolhatjuk a térség államait. A változók között a túlvilági hit mértéke (0-1 skála), Isten fontossága (1-10-es skálán mérve, 10=nagyon fontos), az egyházlátogatás gyakorisága (1-7 skála, $1=$ soha, $7=$ =mindig) és az imádkozás gyakorisága (1-7 skála) szerepelt. A klaszterátlagokat tartalmazza a 3. táblázat, a szegmensek elnevezéseit a klaszterképző sajátosságok alapján adtam meg.

A régióból egyértelműen kitűnik és külön csoportot képez Csehország és Észtország (szekuláris klaszter), hiszen minden vallási mutatója rendkívül alacsony, még a túlvilági létező fontosságát tekintve is. Szintén egyértelműen elkülönül a mezőnytől Lengyelország és Románia (mélyen vallásosak), amely társadalmakra az előzőek antitéziseként erős hitbeli meggyőződés, felekezetlátogatás és imaélet egyszerre jellemző. A térség többsége a két véglet között helyezkedik el, ritka vagy alkalmankénti egyházlátogatással, közepesen erős hitbeli meggyőződéssel. Albánia, Horvátország és Szlovákia abban különül el a középmezőnytől, hogy Isten személye fontosabb szerepet tölt be a lakosság életében és ehhez viszonylag rendszeres felekezeten kívüli hitgyakorlás, imaélet társul. Ez utóbbi sajátosság miatt ragadhatjuk meg a három ország hitgyakorlását az individuális jelzővel.

A közép- és kelet-európai országok csoportosításával közelebb kerülhetünk annak a kérdésnek a megválaszolásához, hogy vajon mely országokban meghatározó a vallás szerepe a társadalmi tőke képződésében. Az elméletek szerint a társadalmi tőke vallási dimenziója azokban az államokban jelentős, 
ahol az intézményesült hitgyakorlás erőteljes. Eszerint Lengyelországban és Romániában a vallási közösségek feltehetően nagyfokú befolyást gyakorolnak a társadalmi tőke képződésére, míg Csehországban és Észtországban e közösségek jelentősége marginálisabb. Kérdéses, hogy vajon a hitgyakorlás intézményesült formáját kevésbé gyakorló két klaszter (individuális hitgyakorló és bizonytalan hívő) tagjaiban milyen mértékben érvényesül a vallási közösségek társadalmi tőkeképződéshez való hozzájárulása, esetleg a humán tőkén keresztül befolyásolják jobban a területi versenyképességet. Kétségkívül további kutatásra ad okot a kérdések megválaszolása, ahogyan a mélyen vallásos és szekuláris államokkal kapcsolatos elméleti feltevések tesztelése is.

\section{Összegzés}

A tanulmány tizenhárom közép- és kelet-európai ország vallási-gazdasági összefüggéseinek vizsgálatából indult ki, majd annak mélyebb tanulságait kereste a területi tőke elméletében. A kiindulásul szolgáló kutatás két fő megállapítása a következő: 1. A térségben minél diverzifikáltabb egy ország felekezeti megoszlása, annál alacsonyabb egyházlátogatási gyakoriság, intézményesült vallásgyakorlás jellemző rá. 2. A hitgyakorlás láncszerü, közvetett kapcsolatot mutat az országos gazdasági indikátorokkal, melyek között az összekötő elem az iskolázottság. Az elemzés fényében régiónkban a vallás a humán tőkébe való befektetésként hat a gazdasági fejlődésre. A vizsgálat azonban nem tért ki a vallás bizalomra, önkéntességre, közéleti aktivitásra gyakorolt hatásaira, így a vallási-gazdasági összefüggések szűk mezsgyéjét tárta fel.

A korábban kapott eredmények kiegészítéseként jelen tanulmány áttekintette azokat a mérvadó szociológiai elméleteket, melyek a vallási közösségek gazdasági hatását elsősorban a társadalmi tőkébe való befektetésként értelmezik. Mindez úgy lehetséges, hogy a vallási közösségek többsége a közös normák, a bizalomépítés, a tolerancia és a szolidaritás terjesztésén keresztül a közjó elömozdításán dolgozik, a közösséghez tartozók aktív önkéntes tevékenységet végeznek, adományoznak a társadalmi célok megvalósulására. Camagni (2008) elmélete szerint mindennek regionális megnyilvánulása a térség endogén fejlödését segíti, a területi tőke felhalmozódásához vezet. Mikroszinten a területi tőke másik fontos immateriális eleme a humán tőke, melynek kapcsolatát a vallással és a gazdasággal már a kiinduló kutatás is tartalmazta. Putnam (2000) és Weiss (1996) elméletei alapján a humán tőke és a társadalmi tőke szinkronban fejlődik, így érthetővé válik, hogyan képes a vallásgyakorlás meghatározni a területi tőkét egyik vagy másik irányon keresztül, mikro- vagy makroszinten.

A tanulmány harmadik része a közép- és kelet-európai országok társadalmi tőkéhez való hozzájárulását vizsgálta. Bár nem elemeztem a vallási aktivitás és a társadalmi tőke indikátorait, a régió országainak csoportosítása megalapozza 
a további kutatásokat. Az individuális és az intézményi (egyházlátogatás) hitgyakorlat aktivitása alapján négy klasztert különítettem el. Az értékkutatások szerint mindkét szempontból alacsony aktivitás jellemzi Csehországot és Észtországot, míg Lengyelország és Románia állampolgárai mély és rendszeres vallási életet gyakorolnak. Az individuális, intézményen kívül aktív hitgyakorlat főként Albánia, Horvátország és Szlovákia sajátja, a többi vizsgált országban (a térség középső és északi blokkja) közepes vagy alacsony személyes hit és ritka egyházlátogatás a mérvadó. A csoportképzés alapján Lengyelországban és Romániában a vallási közösségek feltehetően jelentős szerepet vállalnak a társadalmi tőkeképződésben, míg az individuális hitgyakorló országokban a vallás egyéni hatásának felértékelődésére számíthatunk. A tanulmány záró feltevései további vizsgálatokat igényelnek a vallási aktivitás és a társadalmi tőke különböző indikátorainak kapcsolatáról. Az azonban a szociológiai felmérések eredményei alapján világosan látszik, hogy Közép- és Kelet-Európában a - zömében keresztény - vallási orientáció hozzájárul a regionális identitás keletkezéséhez és fenntartásához.

\section{Jegyzetek}

1 Az empirikus adatok másodelemzése (Balassa 2018a) az Emberi Erőforrások Minisztériuma ÚNKP-17-3 kódszámú Új Nemzeti Kiválóság Programjának támogatásával készült.

2 A protestantizmus gazdasági hatásairól mértékadó tanulmányt írtak Becker, Pfaff, Rubin (2016), a vallás és gazdaság egymásra hatásának szakirodalmáról lásd Balassa (2018c).

3 Az elemzés léptékeként azért is választottam az országos szintet, mert az EVS eredményei ezen a szinten reprezentatívak, NUTS2-es szinten nem. Habár egy 2008-as adatbázis tíz év távlatából elavultnak tűnhet, a kutatás idején ez volt a legfrissebb elérhető adatgyüjtemény, amely mind a tizenhárom ország vallási indikátorait tartalmazta.

4 Az országok szintjén kiszámolt survey-átlagok egyaránt utalhatnak homogén és heterogén vallási környezetre. A válaszok szóródásának felülvizsgálata alapján az országok egy csoportjában (viszonylag homogén vallási háttér) ez nem okozhat problémát (ilyen Csehország, Észtország, Horvátország, Lengyelország, Románia), ugyanakkor a nagyon heterogén vallási hátterủ országokban (Magyarország, Lettország) kizárólag az átlag alapján kevésbé pontosan jellemezhető a populáció.

5 A CIA World Factbook a nemzeti népszámlálási adatokra támaszkodva országos szinten közli a felekezeti megoszlásokat (https://www.cia.gov/library/publications/the-world-factbook/). Az adatbázis a térségi felekezeti megoszlásokat többnyire hét kategóriában (katolikus, protestáns, ortodox, zsidó, muszlim, egyéb és nem vallásos) közli. Némely országban a szabad keresztények és pünkösdi hívők számát is feltüntette, őket a protestáns gyüjtőkategóriához soroltam, valamint helyenként a Jehova Tanúi egyház külön kategóriaként szerepelt, megoszlásukat az egyéb kategóriához soroltam.

6 A Herfindahl-Hirschman-indexszel bizonyos jellemvonások koncentrációját mérik a vizsgált populációban. A Pew Research Center (2014b) módszertana a Herfindahl-Hirschman-index inverzét használja, vagyis a magasabb értékek a felekezetek nagyobb diverzitását mutatják.

7 A vallásosság rendszerváltást követő megerősödésében bizonyosan közrejátszott, hogy a letűnt politikai rendszer igyekezett elfojtani a meggyőződéses hitgyakorlást, a nem bevett egyházakhoz kötődő stigmák miatt pedig rendszeres volt utóbbiak háttérbe szorítása. A '90-es 
években a helyzet megváltozott, csökkentek vagy megszűntek azok a korábbi korlátok, amelyek a perifériára szorították a vallási meggyőződésüket aktívan megélő és felvállaló állampolgárokat, ami az egyházak alapításának és látogatásának is új lendületet adott. A „szekuláris állam, szekuláris politika” szegmensbe sorolja Máté-Tóth (2014) Észtországot, Litvániát, Lettországot, Csehországot, Magyarországot, Szlovéniát, Bulgáriát és Szerbiát. Románia a prototípusa az úgynevezett „szekuláris állam, vallásos politika” megvalósulásának, ahol még Lengyelországot, Szlovákiát és Horvátországot említi példaként a szerző.

\section{Köszönetnyilvánítás}

A tanulmány az Emberi Erőforrások Minisztériuma ÚNKP-18-3 kódszámú Új Nemzeti Kiválóság Programjának támogatásával készült.

\section{Irodalom}

Balassa B. (2018a): A zsidó és keresztény felekezetek hatása Közép- és Kelet-Európa gazdaságára. In: Új Nemzeti Kiválóság Program 2017/2018 Tanulmánykötet. Széchenyi István Egyetem, Győr, $107-115$.

Balassa, B. (2018b): Examining the effects of religion on Central and Eastern European Economy. In: Altaher, A., Focacci, A., Pawlicz, A., Cebeci, K. (eds.): MIRDEC 2018 Conference Proceedings: MIRDEC-7th International Academic Conference Social Science, Multidisciplinary and Globalization Studies (Global Meeting of Social Science Community). Masters International Consultancy Research and Publishing (MIRDEC Publishing), Istanbul, 39-46.

Balassa B. (2018c): Mi köze a vallásnak a gazdasághoz? A vallás és a gazdaság összefüggés-vizsgálatának áttekintése. Tér-Gazdaság-Ember, 2., 129-146.

Barro, R. J., Mccleary, R. M. (2003): Religion and economic growth across countries. American Sociological Review, 5., 760-781. http://doi.org/dfc6mr

Becker, S. O., Woessmann, L. (2010): The effect of Protestantism on education before the industrialization: Evidence from 1816 Prussia. Economics Letters, 2., 224-228. http://doi.org/b9nkvc

Becker, S. O., Pfaff, O., Rubin, J. (2016): Causes and consequences of the protestant reformation. Explorations in Economic History, 62., 1-25. http://doi.org/gfwk4q

Bellah, R. N. (1967): Civil religion in America. Daedalus, 1, 1-21.

Berger, P. L. (1969): The sacred canopy: Elements of a sociological theory of religion. Anchor, New York

Berger, P. L. (1999): The desecularization of the world: resurgent religion and world politics. Ethics and Public Policy Center, Washington

Bourdieu, P. (1979): La distinction. Les Éditions de minuit, Paris

Bruce, S. (2002): God is dead: Secularization in the West. Wiley-Blackwell, Oxford

Butlin, R. (1990): Történeti földrajz, regionális identitás és kulturális régiók összehasonlító elemzése. Tér és Társadalom, 3-4., 1-11. https://doi.org/10.17649/TET.4.3-4.179

Camagni, R. (2008): Regional competitiveness: towards a concept of territorial capital. In: Capello, R., Camagni, R., Chizzolini, B., Fratesi, U. (eds.): Modelling regional scenarios for the enlarged Europe. Springer-Verlag, Berlin, 33-47. http://doi.org/cj7qfq

Coase, R. (1960): The problem of social cost. Journal of Law and Economics, 3.,1-44.

Coleman, J. S. (1988): Social capital in the creation of human capital. The American Journal of Sociology, 94., 95-120.

Cox, E. (1995): A truly civil society. ABC Books, Sydney 
Durkheim, É. (2001 [1893]): A társadalmi munkamegosztásról. Osiris Kiadó, Budapest

Enyedi Gy. (1978): Kelet-Közép-Európa gazdaságföldrajza. Közgazdasági és Jogi Könyvkiadó, Budapest

Fazekas Cs. (2008): Egyházak, egyházpolitika és politikai eszmék az Osztrák-Magyar Monarchiában. Miskolci Egyetem Politikatudományi Intézet, Miskolc (Mühelytanulmányok; 4.)

Forgács A., Csillik P. (2017): Megerősíthető-e mai statisztikai adatokkal Max Weber hipotézise a protestánsok jobb gazdasági teljesítményéről? Confessio, 1., 82-107.

Glahe, F., Vohries, F. (1989): Religion, liberty and economic development: An empirical investigation. Public Choice, 3., 201-215. http://doi.org/b8b82f

Greeley, A. M. (1997): Coleman revisited: religious structures as a source of social capital. American Behavioral Scientist, 5., 587-594. http://doi.org/cdz6d6

Hankiss E. (1991): Nemzetvallás. In: Kovács Á. (szerk.): Monumentumok az első háborúból. Corvina, Budapest, 64-90.

Harrach G. (2013): A magyarországi szekularizáció egyes statisztikai összefüggései: történelmi keresztény egyházak térvesztése a 2011-es népszámlálás tükrében. http://evangelikus.hu/sites/default/files/ szekularizacio_2013.pdf (Letöltés: 2019. április 8.)

Huntington, S. P. (2015): Civilizációk összecsapása és a világrend átalakulása. Európa Könyvkiadó, Budapest

Iannaccone, L. R. (1998): Introduction to the economics of religion. Journal of Economic Literature, 3., $1465-1495$.

Korpics M., Wildmann J. (2010): Vallások és egyházak az egyesült Európában. Typotex Elektronikus Kiadó, Budapest

Lengyel I. (2012): Regionális növekedés, fejlődés, területi tőke és versenyképesség. In: Bajmócy Z., Lengyel I., Málovics Gy (szerk.): Regionális innovációs képesség, versenyképesség és fenntarthatóság. JATEPress, Szeged, 151-174.

Lenin, V. I. (1971 [1915]): Lenin Összes Müvei, 26. kötet. Kossuth Könyvkiadó, Budapest

Lin, N. (2001): Social capital: A theory of social structure and action. Cambridge University Press, Cambridge

Locke, J. (1824 [1689]): The works of John Locke in Nine Volumes. 12th edition. Vol. 5. Rivington, London

Luckmann, T. (1967): The invisible religion: The problem of religion in modern society. Macmillan, New York

Luckmann, T. (1996): A láthatatlan vallás. A vallás fenomenológiája. Lettre, 23.

Máté-Tóth A. (2014): Vallásnézet. A kelet-közép-európai átmenet vallástudományi értelmezése. Korunk, KOMP-Press, Kolozsvár

McGuire, M. B. (2001): Religion: The social context. Wadsworth, Belmont

Nagy G. D. (2016): Társadalmi tóke és területi kötődés Magyarországon. Belvedere Meridionale, Szeged

Niederhauser E. (2001): Kelet-Európa története. História Könyvtár Monográfiák, Budapest

Norris, P., Inglehart, R. (2004): Sacred and secular: Religion and politics worldwide. Cambridge University Press, Cambridge

OECD (2000): Agricultural policies in OECD countries 2000: Monitoring and evaluation, OECD Publishing, Paris http://doi.org/dc4xt7

Onyx, J., Bullen, P. (2000): Measuring social capital in five communities. The Journal of Applied Behavioral Science, 1., 23-42. http://doi.org/dprr8h

Pew Research Center (2014a): Religion in Latin America. Widespread change in a historically catholic region. http://www.pewforum.org/2014/11/13/religion-in-latin-america/ (Letöltés: 2017.június 19.)

Pew Research Center (2014b): Global religious diversity. Methodology. http://www.pew forum.org/2014/04/04/methodology-2/ (Letöltés: 2017. június 19.)

Pew Research Center (2017): Religious belief and national belonging in Central and Eastern Europe. http://www.pewforum.org/2017/05/10/religious-belief-and-national-belonging-in-centraland-eastern-europe/ (Letöltés: 2017. május 25.)

Pickel, G. (2013): Die Situation der Religion in Deutschland - Rückkehr des Religiösen oder voranschreitende Säkularisierung? In: Pickel, G., Hidalgo, O. (Hrsg.): Religion und Politik im vereinigten Deutschland. Springer Fachmedien, Wiesbaden, 65-101. http://doi.org/c39z

Pintér K. (2014): A civil vallás identitásformáló szerepének lehetőségeiről. Civil Szemle, 1., 5-26.

Pollack, D. (2003): Säkularisierung - ein moderner Mythos? Studien zum religiösen Wandel in Deutschland. Mohr, Tübingen

Putnam, R. D., Leonardi, R., Nonetti, R. Y. (1993): Making democracy work: Civic traditions in modern Italy. Princeton University Press, Princeton http://doi.org/c392 
Putnam, R. D. (2000): Bowling alone: the collapse and revival of American community. Simon and Schuster, New York

Rechnitzer J., Smahó M. (2011): Területi politika. Akadémiai Kiadó, Budapest

Schmidt, A. J. (2017): Hogyan változtatta meg a kereszténység a világot? Hetek Könyvek, Budapest

Somlyódyné Pfeil E. (2007): Mozaikok a regionális identitás értelmezéséhez. Tér és Társadalom, 4., 57-71. http://doi.org/c393

Stark, R., Iannaccone, L. R. (1994): A supply-side reinterpretation of the "secularization" of Europe. Journal for the Scientific Study of Religion, 3., 230-252. http://doi.org/b5hzqg

Szőke Á. (szerk.) (1999): Antik eredetű szakszókincs. Athenaeum Kiadó, Budapest

Szücs J. (1983): Vázlat Európa három történeti régiójáról. Magvető Kiadó, Budapest

Tomka, M. (2011): Expanding religion: religious revival in post-communist Central and Eastern Europe. De Gruyter, Berlin. http://doi.org/c394

Tomka, M., Zulehner, P. (2008): Religionen und Kirchen in Ost(mittel)europa. Schwabenverlag, Ostfildern

Weber, M. (1987 [1910]): Gazdaság és társadalom. A megértő szociológia alapvonalai I. Közgazdasági és Jogi Könyvkiadó, Budapest

Weiss, D. A. (1996): Towards a theory on the formation of social capital. Doctoral thesis, University of Minnesota, Minneapolis

Wuthnow, R. (1999): Mobilizing civic engagement: The changing impact of religious involvement. In: Skocpol, T., Fiorina, M. P. (eds.): Civic engagement in American Democracy. Brookings Institution Press, Washington, 331-363.

Young, C. (2009): Religion and economic growth in Western Europe: 1500-2000. http://web. stanford.edu/ cy10/public/Religion_and_Economic\%20Growth_Western_Europe.pdf (Letöltés: 2017. december 18.) 